\title{
Article \\ Quality and Yield of Lettuce in an Open-Air Rooftop Hydroponic System
}

\author{
Maha Ezziddine * and Helge Liltved
}

Citation: Ezziddine, M.; Liltved, $\mathrm{H}$ Quality and Yield of Lettuce in an Open-Air Rooftop Hydroponic System. Agronomy 2021, 11, 2586. https: / / doi.org/10.3390/ agronomy11122586

Academic Editors: Nikos Tzortzakis, Daniele Massa and Bart Vandecasteele

Received: 5 November 2021

Accepted: 14 December 2021

Published: 19 December 2021

Publisher's Note: MDPI stays neutral with regard to jurisdictional claims in published maps and institutional affiliations.

Copyright: (C) 2021 by the authors. Licensee MDPI, Basel, Switzerland. This article is an open access article distributed under the terms and conditions of the Creative Commons Attribution (CC BY) license (https:/ / creativecommons.org/licenses/by/ $4.0 /)$.
Department of Engineering Sciences, University of Agder, 4898 Grimstad, Norway; helge.liltved@uia.no * Correspondence: maha.ezziddine@uia.no

\begin{abstract}
In this study, the yield and growth performance of lettuce in an open-air rooftop hydroponic system were investigated. Lettuce was grown in a closed recirculating nutrient film technique (NFT) unit using a standard nutrient solution (NS). Yield, fresh weight, and nutrient content in the leaf tissue of the harvested lettuce were measured. The results were compared with the results obtained in indoor hydroponic lettuce growth with artificial lightning. Despite strong winds during the growth period, $25 \%$ of the total lettuce heads weighed twice the marketable weight; however, $25 \%$ of the total lettuce heads were below the marketable weight. A more efficient nutrient uptake was indicated by the lettuces in the rooftop system compared with the uptake in the indoor system. Foliar analysis revealed a higher content of all nutrients in the leaves of rooftop hydroponic lettuce compared with indoor hydroponic lettuce. This study suggests that hydroponic rooftop-grown lettuce can be competitive with their indoor counterparts if the rooftop hydroponic system is protected from extreme weather conditions.
\end{abstract}

Keywords: rooftop hydroponic; nutrient film technique; indoor hydroponic

\section{Introduction}

Urban farming may tackle many challenges that conventional agriculture is facing, including loss of arable land, water and nutrients depletion, fast population growth, soil contamination, rapid urbanization, and climate change [1]. One type of urban farming is rooftop farming, which is the practice of growing edible or ornamental plants on top of commercial, residential, and industrial buildings [2]. The majority of the roof space in most buildings is vacant. If this space is used for agriculture, it could meet up to $77 \%$ of inhabitants' vegetable requirements [3]. Liu et al. reported that [4] they grew seven leafy vegetables in rooftop hydroponic systems and reported that rooftop hydroponic vegetables were less contaminated and were competitive in quality and cost compared with farm-grown leafy vegetables. Another study reported that $32 \%$ of the needed fresh produce in Cleveland USA could be satisfied if $62 \%$ of industrial and commercial rooftops were used to grow plants [5].

Rooftop farming could also alleviate environmental pollution by reducing the carbon dioxide in the atmosphere and helping clear the air of smog and dust [4]. Further environmental benefits of rooftop farming include water runoff management, reduction in the urban heat island effect, biodiversity conservation, and reduction in noise pollution [6].

Contrary to indoor urban farming, which relies on artificial lightning, rooftop farming can be cost effective because it uses only sunlight. Despite the advantages of rooftop farming and worldwide interest, commercial rooftop farms are very limited and most of extant roof farms are social-educational farms [7]. One reason for this could be the challenges that roof farming may face, including amplified climate conditions that can occur on rooftops, such as high wind speed, heavy rains, and extreme temperatures [6]. In addition, roofs are not designed, generally, for urban farming, which poses many obstacles that must be overcome before rooftop farming can spread more widely, such as roof weight limitations and installation and maintenance costs [8]. Another reason could be the lack of assessment 
studies on the practicality of rooftop farming compared with conventional or indoor urban farming. Recently, the number of articles on rooftop farming has increased [8-31]. However, our literature search found very few research articles comparing rooftop grown vegetables against their rural farm or greenhouse counterparts [4,31]. Liu et al. [4] reported that leafy vegetables grown in rooftop hydroponic systems, including lettuce, mustard, caraway, and Chinese flowering cabbage, can be as productive in yield and quality as those sold by local farms. No comparative studies between rooftop hydroponic and indoor hydroponic vegetables were found. Therefore, the aim of this study was to investigate hydroponic lettuce grown in a rooftop system in Norway. The performance of the rooftop hydroponic system was assessed by cultivation experiments, where the fresh weight of the lettuce, the yield, and the nutrients in the leaf tissue were measured. The results were compared to results obtained in an indoor hydroponic system with artificial lightning.

\section{Materials and Methods}

\subsection{Indoor Hydroponic Lettuce Growth}

Indoor hydroponic lettuce growth was performed in a growth room located at the University of Agder in Norway from 27 September to 4 December 2018. The growth systems consisted of a seeding system and a nutrient film technique (NFT) system. In the seeding system, seeds of Lactuca sativa L. (Batavia-type, cv. 'Partition') from LOG AS, Norway were seeded in Grodan rockwool cubes $(36 \times 36 \times 40 \mathrm{~mm})$, placed in trays with NS, and illuminated with LED light. The seedlings were inserted into net pots and transplanted to the NFT system after 2 weeks in the seeding system. The NFT system included three identical parallel units designed for conducting triplicate experiments under identical conditions. Each unit hosted 12 lettuces in a cloosed loop system, which consisted of a rectangular PVC pipe and a $20 \mathrm{~L}$ nutrient tank. The PVC pipe was $2400 \mathrm{~mm}$ long and $100 \mathrm{~mm}$ wide and had 12 holes with diameters of $45 \mathrm{~mm}$ for net pots. The nutrient tank had a submerged pump, which intermittently supplied the PVC pipe (30 min on/off cycles) with NS at a flow rate of $3.5 \mathrm{~L} \mathrm{~min}^{-1}$.

LED lamps were suspended over the PVC pipes, producing photosynthetically active radiation (PAR) with a flux density of $220 \mu \mathrm{mol} \mathrm{m}^{-2} \mathrm{~s}^{-1}$ for $18 \mathrm{~h}$ per day. The temperature of the growth room was in the range of $22-24{ }^{\circ} \mathrm{C}$, the $\mathrm{CO}_{2}$ concentration was in the range $410-450 \mathrm{ppm}$, and the relative humidity was $35-40 \%$.

The NS was prepared from two commercial stock solutions, Nutri-A and Nutri-B, purchased from Panponic Biosystems AS, Norway. Nutrient content of the applied NS is shown in Table 1. Every second day, $\mathrm{pH}$ and EC values of the three parallel systems were adjusted to maintain the $\mathrm{pH}$ at 5.5-6.5 and the EC value at $1.1-1.2 \mathrm{mS} \mathrm{cm}^{-1}$ using a calibrated Hach HQ40d instrument with standard pH and EC sensors. Each of the three parallel units of the NFT system was operated in a similar continuous production mode during the experimental period. At the starting date (27 September 2018), 9 seedlings ( 2 weeks old) were collected from the seedling system and transferred to the NFT system (3 seedlings to each of the three units). After 4 weeks, the NFT system was fully stocked, and the first 3 lettuce heads of each unit were harvested and replaced by 3 new seedlings ( 2 weeks old). During the 68 days experimental period from 27 September to 4 December, there were 7 harvests (on 25 and 31 October, and 6, 13, 21, and 27 November, and 4 December), with a total production of 21 lettuce heads from each unit, which gave a total of 63 lettuce heads from the 3 parallel units of the NFT system.

Table 1. Soluble nutrient content of the applied nutrient solution in this study.

\begin{tabular}{cccccccccccccc}
\hline & $\begin{array}{c}\mathbf{N O}_{3^{-}} \\
\mathbf{N}\end{array}$ & $\begin{array}{c}\mathbf{N H}_{4^{-}} \\
\mathbf{N}\end{array}$ & $\mathbf{P}$ & $\mathbf{K}$ & $\mathbf{C a}$ & $\mathbf{M g}$ & $\mathbf{S}$ & $\mathbf{Z n}$ & $\mathbf{B}$ & $\mathbf{C u}$ & $\mathbf{F e}$ & $\mathbf{M n}$ & $\mathbf{M o}$ \\
\hline $\mathrm{mg} \mathrm{L}^{-1}$ & 107 & 4.0 & 23 & 140 & 94 & 23 & 23 & 0.26 & 0.19 & 0.07 & 1.7 & 0.42 & 0.04 \\
\hline
\end{tabular}


Samples from the nutrient tank were taken throughout the growth period for nutrient analysis. Soluble nutrient analysis was performed using inductively coupled plasma optical emission spectrometry (ICP-HSP), according to accredited standards by the Eurofins laboratory, Netherlands. Lettuce was harvested and weighed after 4 weeks in the NFT systems. Leaf tissue samples from different parts of the harvested lettuces were collected and analyzed for macro- and micro-nutrient content by inductively coupled plasma atomic emission spectrometry (ICP-OES), according to European standards (DIN EN ISO 11885).

\subsection{Open-Air Rooftop Hydroponic Lettuce Growth}

Seeds of Lactuca sativa L. (Batavia-type, cv. 'Partition') from LOG AS, Norway, were seeded in a seeding system as described above. Seedlings were then transplanted in an open-air rooftop hydroponic system. Open-air rooftop hydroponic lettuce growth was carried out from the 25 August to 6 October 2020 in an NFT hydroponic system, installed on the fifth floor rooftop of one building of the University of Agder in Norway, as described in Figure 1. The yellow area, no. 6, in Figure 1a is reserved for rooftop farming.

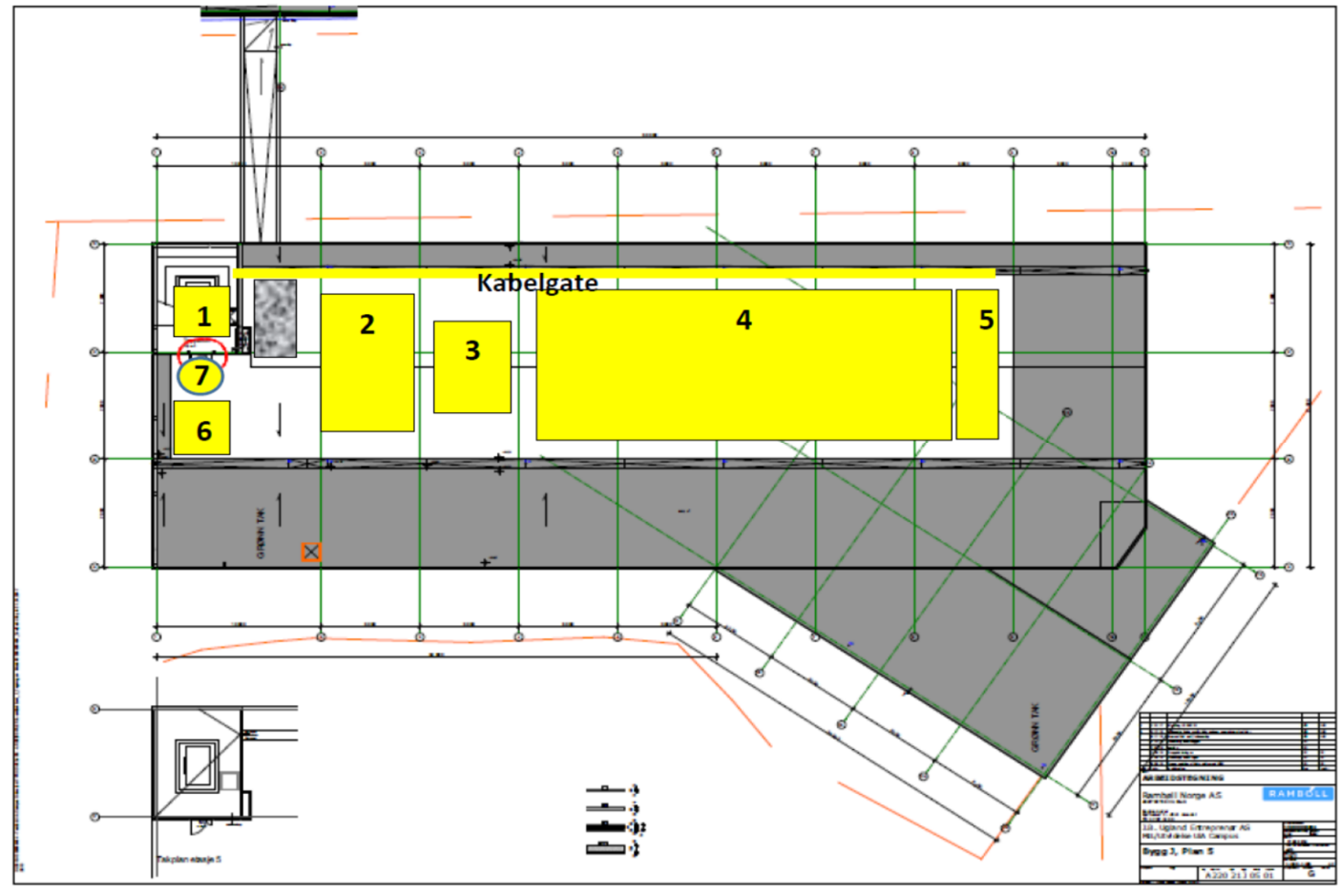

(a)

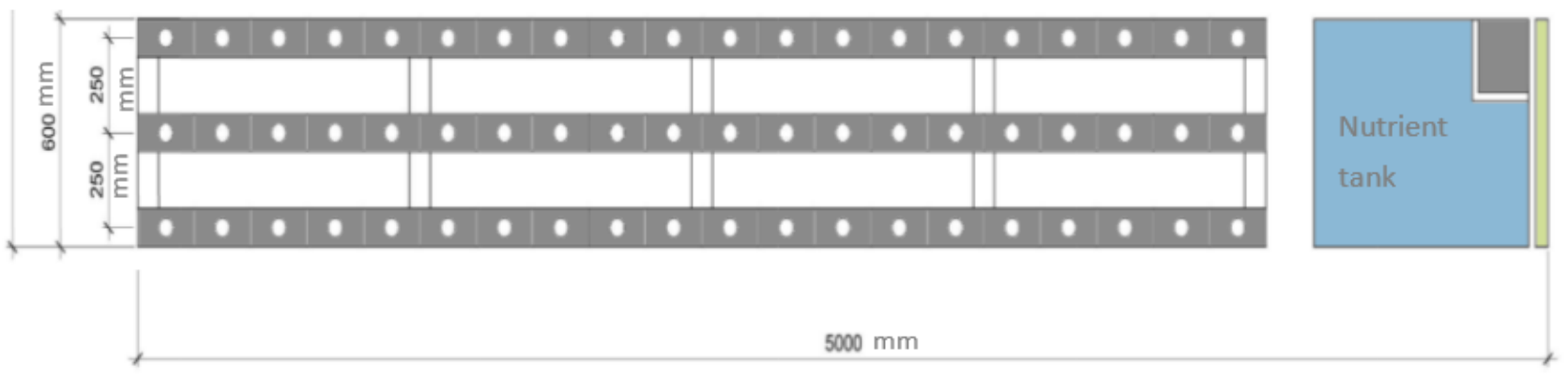

(b)

Figure 1. Principle drawing of the fifth floor rooftop of one building of the University of Agder in Norway (a) and drawing of the experimental rooftop hydroponic system $(\mathbf{b})$. 
High wind speed and heavy precipitation incidences at the beginning of the period gave the seedlings a hard and slow start and many of them were damaged. Due to nonoptimal weather conditions, the trial lasted five weeks instead of four. The NFT system was made of 3 rectangular PVC pipes, each $4000 \mathrm{~mm}$ long and $100 \mathrm{~mm}$ wide, mounted in an aluminum stand with wind shields. Each pipe had 20 holes with $50 \mathrm{~mm}$ diameter for inserting net pots, which allowed the cultivation of 60 lettuce heads. A nutrient container intermittently supplied the three PVC pipes with NS (30 min on/off cycles) at a flow rate of $3.5 \mathrm{~L} \mathrm{~min}^{-1}$. Same seeds and NS were used for the rooftop and the indoor hydroponic lettuce growth (Table 1). The $\mathrm{pH}$ and EC of the NS were monitored and adjusted every 2nd day to the same values as in the indoor growth system (5.5-6.5 and $1.1-1.2 \mathrm{mS} \mathrm{cm}^{-1}$ ), respectively. The average PAR throghout the experimental period was $272 \mu \mathrm{mol} \mathrm{m}^{-2} \mathrm{~s}^{-1}$, and the daily average registred PARs (calculated from the recorded data of GHI irradiance by solar iriadiance sensor) are shown in Figure 2.

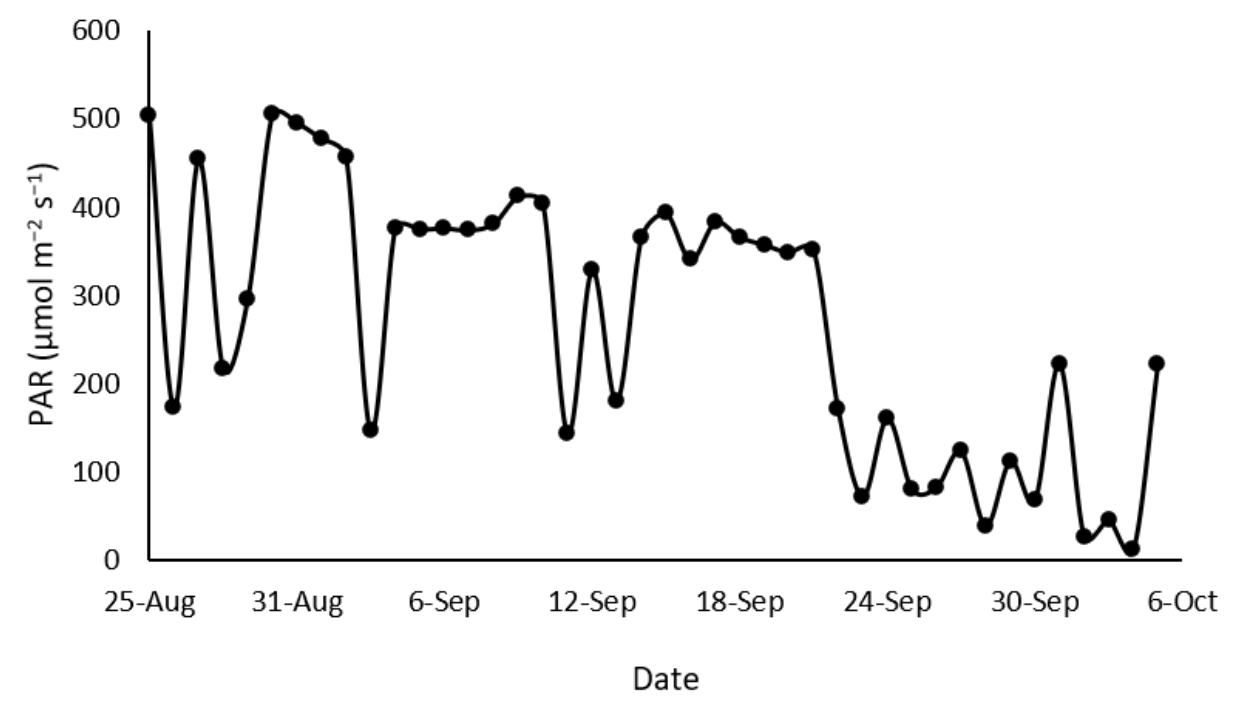

Figure 2. Daily average photosynthetically active radiation (PAR) from 25 August to 5 October 2020.

The average wind speed throughout the experimental period was $1.8 \mathrm{~m} \mathrm{~s}^{-1}$ and the daily average registered wind speeds, recorded by wind speed sensor, are presented in Figure 3. The registered temperature was in the range of $12-22^{\circ} \mathrm{C}$, as shown in Figure 3 , with an average temperature of $16.5^{\circ} \mathrm{C}$. The relative humidity was in the range of $45-69 \%$ and the $\mathrm{CO}_{2}$ concentration was measured to $350 \mathrm{ppm}$ by Elma Dt air monitoring sensor. Leaf tissue samples and NS samples (five samples) were collected and analyzed for macroand micro-nutrient content, as described above.

\subsection{Data Analysis and Statistics}

Data were subjected to analysis of variance (ANOVA) using SPSS Version 25. Mean differences were determined by Tukey's honestly significant difference (HSD) test at $p<0.05$. In figures, statistically significant differences are indicated by different letters. Mean values and standard deviations are presented in the graphs. 


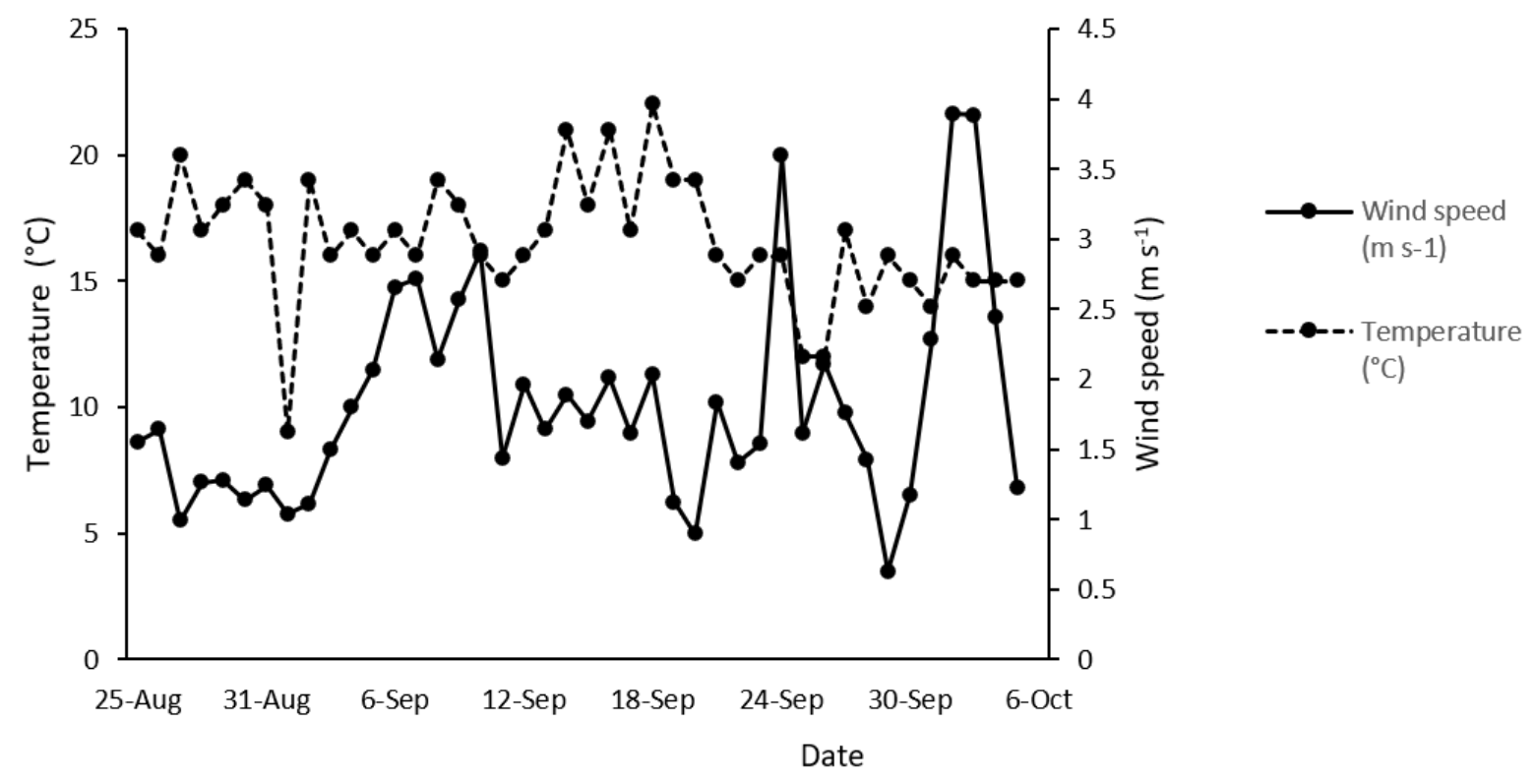

Figure 3. Daily average temperature and daily average wind speed $\left(\mathrm{m} \mathrm{s}^{-1}\right)$ from 25 August to 5 October 2020.

\section{Results and Discussion}

\subsection{Lettuce Growth and Yield}

Shoot fresh weights and yields of the harvested rooftop and indoor hydroponic lettuce are presented in Figure 4. The lettuce grown in the indoor hydroponic system and in the rooftop hydroponic system had an average shoot weight of $243 \mathrm{~g}$ and $233 \mathrm{~g}$, respectively. The maximum and the minimum shoot fresh weights of the indoor and rooftop hydroponic lettuce were $322 \mathrm{~g}$ and $196 \mathrm{~g}$, and $781 \mathrm{~g}$ and $36 \mathrm{~g}$, respectively. Although the average shoot fresh weight of the rooftop hydroponic lettuce was higher than the marketable fresh weight of $150 \mathrm{~g}, 25 \%$ of the total lettuce heads were below the marketable fresh weight. This variation was probably due to the high wind speed experienced during the beginning and at the end of the growth period, as shown in Figure 3.

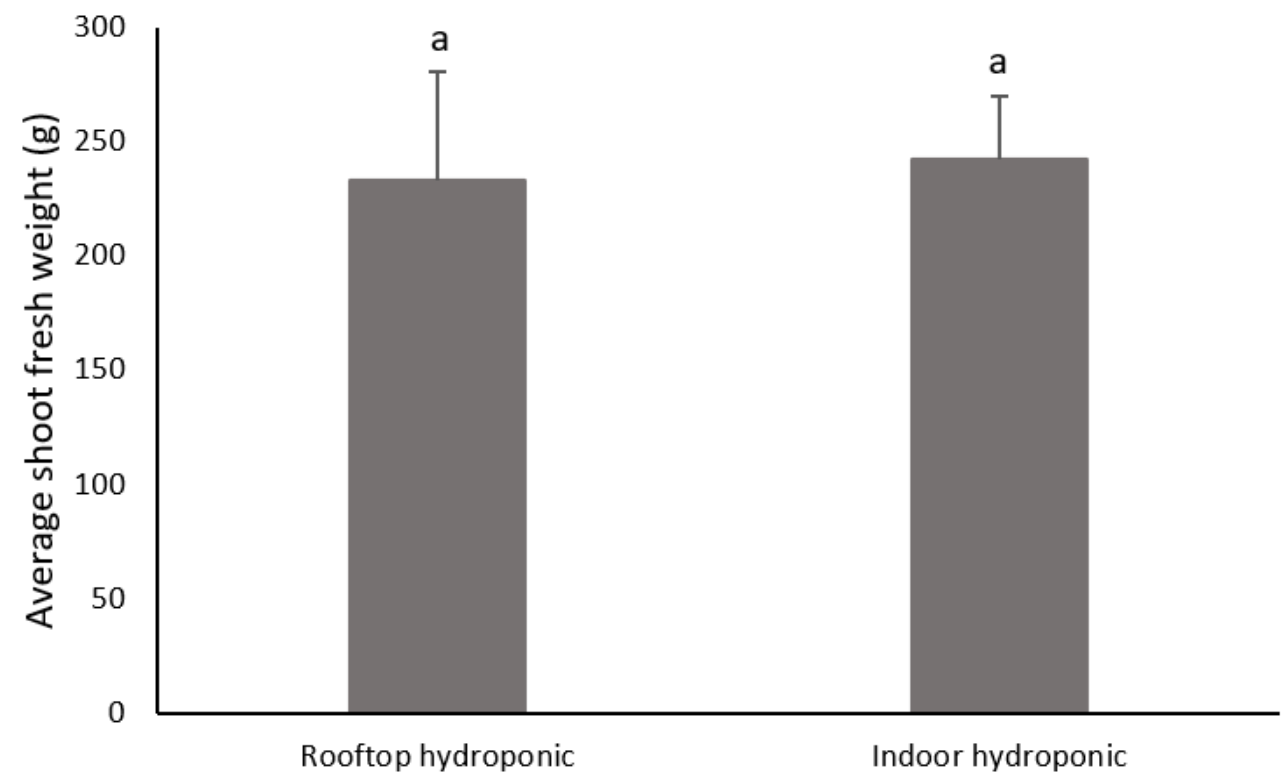

Figure 4. Average shoot fresh weight of rooftop and indoor hydroponic lettuce (bars represent standard deviation of the mean of 60 lettuce heads). 
Another $25 \%$ of the total rooftop lettuce heads weighed twice the marketable fresh weight and $8 \%$ weighed more than $500 \mathrm{~g}$. These lettuce were close to the fence that surrounds one side of the hydroponic system. This study suggests that rooftop hydroponic lettuce could be successfully cultivated in Norway during late season at low temperatures $\left(12-21^{\circ} \mathrm{C}\right)$ if the hydroponic system is protected from the wind.

\subsection{Nutrient Consumption and Concentration in Lettuce Leaves}

Leaf macro- and micro-nutrient concentrations in harvested rooftop hydroponic lettuce, compared to their concentrations in harvested indoor hydroponic lettuce, are shown in Figure 5. The foliar analysis of the macro-nutrients shows that the elements with highest accumulation in leaf tissue of the rooftop hydroponic lettuce were $\mathrm{K}$, followed by N, Ca, P, $\mathrm{Mg}$, and S, which conform to the norm-values of Hartz et al. However, macro-nutrients content in the leaves of the indoor hydroponic lettuce deviates from these norm-values by a higher $\mathrm{N}$ value than $\mathrm{K}$ value.
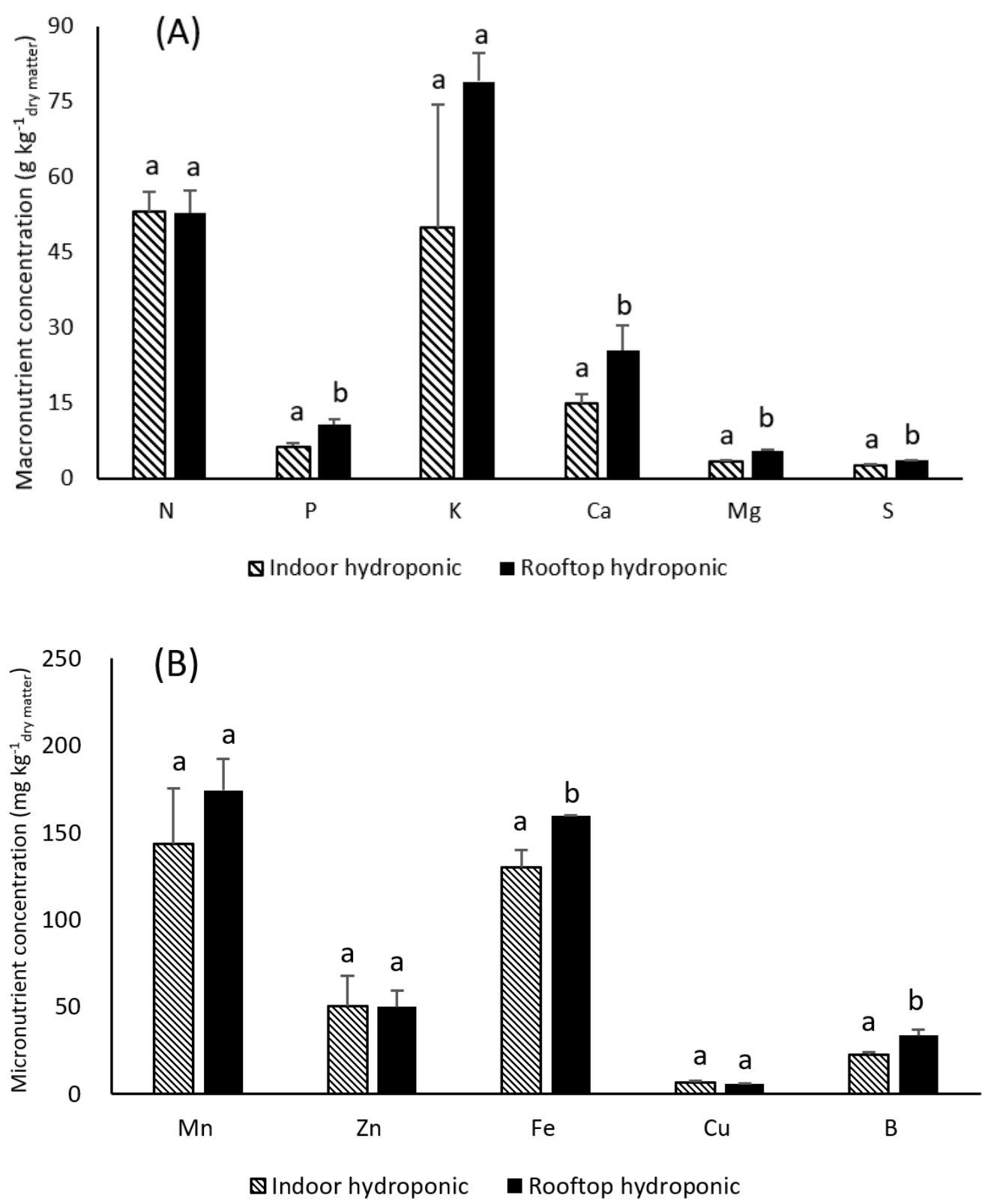

Figure 5. Leaf macro-nutrient (A) and micro-nutrient (B) concentrations in harvested rooftop and indoor hydroponic lettuce (bars represent standard deviation of the mean of three replicas). 
The highest accumulation of micro-nutrient elements in the leaf tissue of both the rooftop and indoor hydroponic lettuce were $\mathrm{Mn}, \mathrm{Fe}, \mathrm{Zn}, \mathrm{B}$, and $\mathrm{Cu}$.

As shown in Figure 5, the rooftop hydroponic lettuce accumulated more nutrients than the indoor hydroponic lettuce. The rooftop lettuce had a significantly higher concentrations of $\mathrm{P}, \mathrm{Ca}, \mathrm{S}, \mathrm{Mg}, \mathrm{Fe}$, and $\mathrm{B}$ compared with the indoor lettuce. There were no significant differences in the other nutrient concentrations. Explanation for this higher uptake could be the positive effect of daylight on nutrients uptake. The intensity of light causes more transpiration in plants which affects nutrients [32]. Rouphel et al. [33] reported that the total plant uptake of $\mathrm{N}, \mathrm{P}, \mathrm{K}, \mathrm{Ca}$, and $\mathrm{Mg}$ is usually enhanced by stronger natural radiation or supplemental light. Another study demonstrated that N, K, Ca, and $\mathrm{Mg}$ concentrations in the leafy lettuce were positively affected by light intensity [34]. Our results are in line with the findings of these previous studies as our rooftop hydroponic lettuce were exposed to stronger natural radiation $\left(272 \mu \mathrm{mol} \mathrm{m}^{-2} \mathrm{~s}^{-1}\right)$ compared with the indoor hydroponic lettuce $\left(220 \mu \mathrm{mol} \mathrm{m} \mathrm{m}^{-2} \mathrm{~s}^{-1}\right)$.

Generally, the nutrient content of the indoor hydroponic lettuce was closer to the norm-values than the nutrient content of the rooftop hydroponic lettuce. $\mathrm{Ca}, \mathrm{P}, \mathrm{K}$, and $\mathrm{Mg}$ all accumulated in the leaves of the rooftop lecttuce, to concentrations 3, 2, 1.5, and 1.5 times the norm-values [35]. This higher absorption of nutrients did not affect lettuce yield for better, nor for worse, as shown in Figure 4.

In order to avoid a possible luxury absorption of nutrients, an alternative NS may be used to grow rooftop hydroponic lettuce exposed to the same environment conditions as those in the current study. The estimation of the required nutrient concentrations of the alternative NS should take into account that not all the available nutrients will be taken up by lettuce leaves. The nutrient consumption and the nutrient uptake in leaves are presented in Table 2, as percentages of the amount of nutrients added to the system. As indicated in Table 2, not all the consumed nutrients were used by lettuce. Some of them may be consumed by microorganism populations. Beatrix et al. [36] reported that they found $10^{6} \mathrm{cfu} \mathrm{m}^{-1}$ bacteria and 10 to 1000 fungi $\mathrm{cfu} \mathrm{ml}^{-1}$ in a closed NFT hydroponic system.

Table 2. Nutrient consumption in rooftop hydroponic system and nutrient uptake by letuce leaves.

\begin{tabular}{ccc}
\hline & $\begin{array}{c}\text { Nutrient Consumption *1 } \\
\left(\mathbf{g} / \mathbf{k g}_{\text {dry matter }}\right)\end{array}$ & $\begin{array}{c}\text { Nutrient Uptake * 2 } \\
\text { (\%) }\end{array}$ \\
\hline Macro-nutrients & 2.95 & \\
N & 0.44 & 63.27 \\
P & 4.2 & 87.74 \\
K & 0.43 & 67.4 \\
Mg & 2 & 44.8 \\
Ca & 0.67 & 46.86 \\
S & & 19 \\
Micro-nutrients & 0.003 & 40.52 \\
Cu & 0.00043 & 47.5 \\
Mn & 0.012 & 54.57 \\
Mo & 0.00053 & 10.7 \\
Zn & 0.003 & 52.7 \\
Fe & 0.03 & 19.13 \\
\hline
\end{tabular}

\footnotetext{
* 1 Nutrient consumption ( $\mathrm{g} / \mathrm{kg}_{\text {dry matter }}$ ) is calculated by subtracting the quantity of nutrient left in the nutrient tank from the total supplied nutrient, then divided by the quantity of the produced dry matter. ${ }^{2}$ Nutrient uptake is calculed by dividing nutrient content in lettuce leaves by nutrient consumption.
}

\subsection{Nutrient Dynamic of the Recycled Solution}

Figure 6 shows the fate of macro-nutrients during the growth period of the rooftop and indoor hydroponic lettuce. As indicated, a continous decrease in the concentration of $\mathrm{P}$ was observed in the NS used for indoor lettuce growth. However, the concentration of $\mathrm{P}$ in the NS used for rooftop lettuce growth increased gradually from $26 \mathrm{mg} \mathrm{L}^{-1}$ to 
$43 \mathrm{mg} \mathrm{L}^{-1}$, despite the high accumulation of $\mathrm{P}$ in the rooftop lettuce leaves compared with norm-values and to the indoor lettuce (Figure 5). The N concentration in the NS used for indoor lettuce growth was reduced by $55 \%$ compared with the initial concentration, while the concentration of $\mathrm{N}$ in the NS used for rooftop lettuce growth remained nearly stable throughout the growth period. The $\mathrm{N}$ accumulation in leaf tissue was approximately equal to the accumulation in the leaves of the indoor hydroponic lettuce. The concentration of $\mathrm{K}$ experienced a continous decrease to final concentrations of $4.7 \mathrm{mg} \mathrm{L}^{-1}$ and $39 \mathrm{mg} \mathrm{L}^{-1}$, in the NS used for indoor hydroponic lettuce and rooftop hydroponic lettuce, respectively, which corresponds to a reduction by $96 \%$ and $75 \%$, respectively. Again, rooftop hydroponic leaf tissue accumulated more $\mathrm{K}$ than the indoor hydroponic leaf tissue.
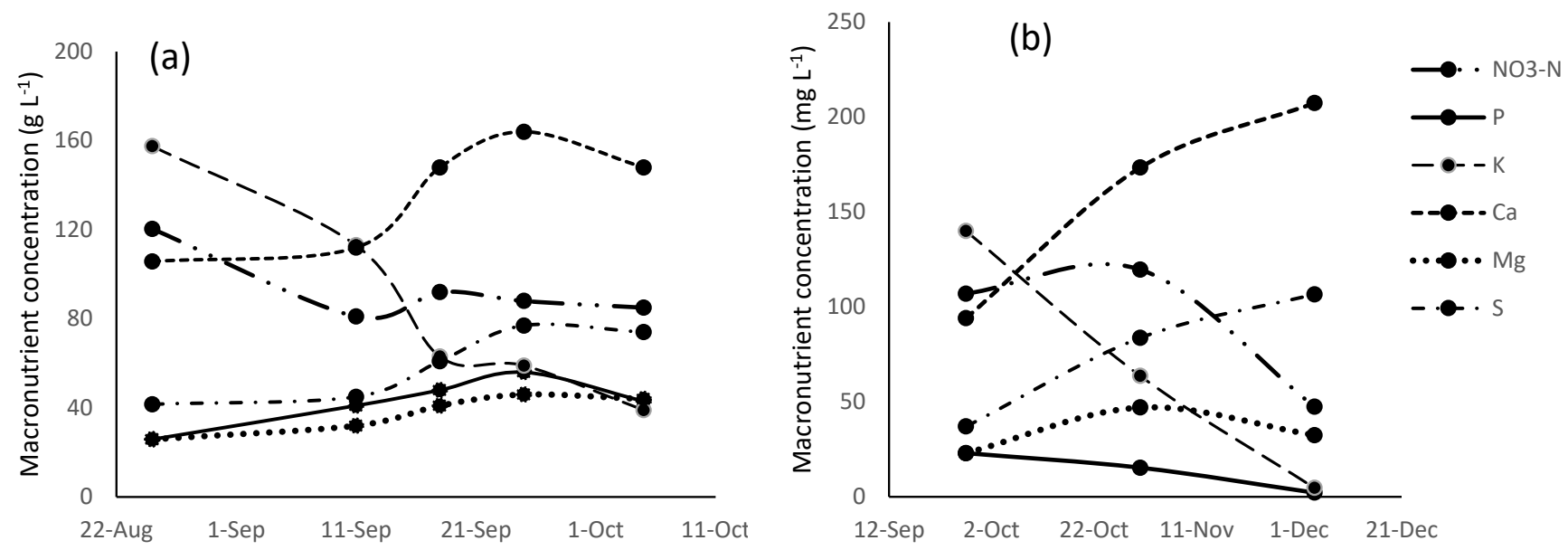

Figure 6. Concentrations of macro-nutrients in the recirculating nutrient solution in rooftop hydroponic system (a) and indoor hydroponic system (b).

To summarize, except for $\mathrm{Ca}$ and S, rooftop lettuce accumulated more nutrients than the indoor lettuce. The concentration of nutrients in the NS used for rooftop lettuce growth were slightly higher at the end of the cultivation period compared with the concentration in the NS used for indoor lettuce growth. Hence, we may deduce two conclusions.

First, the nutrient uptake in rooftop hydroponic lettuce were more efficient than the uptake of indoor lettuce.

Secondly, nutrients were more likely to be wasted (not used by plants) in the indoor hydroponic system. Potentially, this could be partly explained by higher micobial activity due to higher temperature in the indoor hydroponic system compared with the outdoor hydroponic system. However, our literature search found no studies supporting this hypothesis.

We demonstrated in this study that hydroponic rooftop-grown lettuce can be competitive with their indoor counterparts if the rooftop hydroponic system is protected from extreme weather conditions. This study sugggets that rooftop hydroponic systems could not only contribute to urban food production, but could also have a lower environmental footprint, since they use only sunlight and consume less nutrients compared with indoor systems and conventional agriculture, which make them more economical in the long term.

\section{Conclusions}

In this study, we successfully grew lettuce in an outdoor rooftop hydroponic system during late season in Norway. The average fresh weight of the harvested lettuce exceeded the marketed size of commercial lettuce of $150 \mathrm{~g}$. However, $25 \%$ of lettuce heads were below the marketable weight, owing to strong winds during the growth period, while lettuce heads which were close to the fence that surrounds one side of the hydroponic system weighed more than $500 \mathrm{~g}$. Hence, we recommend that special consideration should be taken for open-air rooftop hydroponic installation, such as wind shields. Despite the strong winds, which led to $25 \%$ of undersized lettuce, the average fresh weight of the rooftop 
hydroponic lettuce were statistically comparable to their indoor counterparts. Rooftop hydroponic lettuce leaves accumulated more nutrients than the indoor lettuce. This study confirmed the productive capacity of rooftop hydroponics; nevertheless, a larger scale study should be conducted.

Author Contributions: Conceptualization, M.E. and H.L.; methodology, M.E. and H.L.; software, M.E.; validation, H.L.; formal analysis, M.E.; investigation, M.E. and H.L.; resources, H.L.; data curation, M.E.; writing-original draft preparation, M.E.; writing-review and editing, H.L.; visualization, M.E.; supervision, H.L.; project administration, H.L.; funding acquisition, H.L. All authors have read and agreed to the published version of the manuscript.

Funding: This research was funded by the University of Agder. Grant number: 163831-100.

Institutional Review Board Statement: Not applicable.

Informed Consent Statement: Not applicable.

Data Availability Statement: Data supporting reported results are shown in the present article as tables and figures. The original data are available as Excel files, stored by the first author.

Conflicts of Interest: The authors declare no conflict of interest. The funders had no role in the design of the study; in the collection, analyses, or interpretation of data; in the writing of the manuscript; or in the decision to publish the results.

\section{References}

1. Kozai, T.; Niu, G. Resource- saving and resource-consuming characteristics of PFALs. In Plant Factory an Indoor Vertical Farming System for Efficient Quality Food Production; Kozai, T., Niu, G., Takano, M., Eds.; Academic Press: Cambridge, MA, USA, 2016; pp. 395-400. ISBN 9780128017753.

2. Sabeh, N. Rooftop plant production systems in urban areas. In Plant Factory: An Indoor Vertical Farming System for Efficient Quality Food Production; Kozai, T., Niu, G., Takagaki, M., Eds.; Elsevier Inc.: New York, NY, USA, 2019; pp. 129-135. ISBN 9780128166918.

3. Orsini, F.; Gasperi, D.; Marchetti, L.; Piovene, C.; Draghetti, S.; Ramazzotti, S.; Bazzocchi, G.; Gianquinto, G. Exploring the production capacity of rooftop gardens (RTGs) in urban agriculture: The potential impact on food and nutrition security, biodiversity and other ecosystem services in the city of Bologna. Food Secur. 2014, 6, 781-792. [CrossRef]

4. Liu, T.; Yang, M.; Han, Z.; Ow, D.W. Rooftop production of leafy vegetables can be profitable and less contaminated than farm-grown vegetables. Agron. Sustain. Dev. 2016, 36, 41. [CrossRef]

5. Grewal, S.S.; Grewal, P.S. Can cities become self-reliant in food? Cities 2012, 29, 1-11. [CrossRef]

6. Appolloni, E.; Orsini, F.; Specht, K.; Thomaier, S.; Sanyé-Mengual, E.; Pennisi, G.; Gianquinto, G. The global rise of urban rooftop agriculture: A review of worldwide cases. J. Clean. Prod. 2021, 296, 126556. [CrossRef]

7. Su, Y.L.; Wang, Y.F.; Ow, D.W. Increasing effectiveness of urban rooftop farming through reflector-assisted double-layer hydroponic production. Urban For. Urban Green. 2020, 54, 126766. [CrossRef]

8. Walters, S.A.; Midden, K.S. Sustainability of urban agriculture: Vegetable production on green roofs. Agriculture 2018, 8, 168. [CrossRef]

9. Allaby, M.; MacDonald, G.K.; Turner, S. Growing pains: Small-scale farmer responses to an urban rooftop farming and online marketplace enterprise in Montréal, Canada. Agric. Human Values 2021, 38, 677-692. [CrossRef]

10. Harada, Y.; Whitlow, T.H. Urban Rooftop Agriculture: Challenges to Science and Practice. Front. Sustain. Food Syst. 2020, 4 , 1-8. [CrossRef]

11. Harada, Y.; Whitlow, T.H.; Russell-Anelli, J.; Walter, M.T.; Bassuk, N.L.; Rutzke, M.A. The Heavy Metal Budget of an Urban Rooftop Farm. Sci. Total. Environ. 2019, 660, 115-125. [CrossRef]

12. Specht, K.; Sanyé-Mengual, E. Risks in urban rooftop agriculture: Assessing stakeholders' perceptions to ensure efficient policymaking. Environ. Sci. Policy 2017, 69, 13-21. [CrossRef]

13. Nadal, A.; Llorach-Massana, P.; Cuerva, E.; López-Capel, E.; Montero, J.I.; Josa, A.; Rieradevall, J.; Royapoor, M. Buildingintegrated rooftop greenhouses: An energy and environmental assessment in the mediterranean context. Appl. Energy 2017, 187, 338-351. [CrossRef]

14. Huang, A.; Chang, F.J. Prospects for rooftop farming system dynamics: An action to stimulate water-energy-food nexus synergies toward green cities of tomorrow. Sustainability 2021, 13, 9042. [CrossRef]

15. Harada, Y.; Whitlow, T.H.; Bassuk, N.L.; Russell-Anelli, J. Rooftop Farm Soils for Sustainable Water and Nitrogen Management. Front. Sustain. Food Syst. 2020, 4, 123. [CrossRef]

16. Harada, Y.; Whitlow, T.H.; Templer, P.H.; Howarth, R.W.; Todd Walter, M.; Bassuk, N.L.; Russell-Anelli, J. Nitrogen biogeochemistry of an Urban rooftop farm. Front. Ecol. Evol. 2018, 6, 153. [CrossRef]

17. Zambrano-Prado, P.; Orsini, F.; Rieradevall, J.; Josa, A.; Gabarrell, X. Potential Key Factors, Policies, and Barriers for Rooftop Agriculture in EU Cities: Barcelona, Berlin, Bologna, and Paris. Front. Sustain. Food Syst. 2021, 5, 333. [CrossRef] 
18. Boneta, A.; Rufí-Salís, M.; Ercilla-Montserrat, M.; Gabarrell, X.; Rieradevall, J. Agronomic and environmental assessment of a polyculture rooftop soilless urban home garden in a mediterranean city. Front. Plant Sci. 2019, 10, 341. [CrossRef]

19. Reviews, C. Cost effective precision based rooftop farming. J. Crit. Rev. 2020, 7, 2252-2261.

20. Pant, G.; Keitsch, M. Incorporating Rooftop Farming in Urban Residential Household of Buddhanagar Neighborhood, Kathmandu. In Proceedings of the 8th IOE Graduate Conference, 2020; Volume 8914, pp. 263-271. Available online: http://conference.ioe.edu. $\mathrm{np} /$ ioegc8/papers/ioegc-8-033-80045.pdf (accessed on 4 November 2021).

21. Sanyé-Mengual, E.; Anguelovski, I.; Oliver-Solà, J.; Montero, J.I.; Rieradevall, J. Resolving differing stakeholder perceptions of urban rooftop farming in Mediterranean cities: Promoting food production as a driver for innovative forms of urban agriculture. Agric. Human Values 2016, 33, 101-120. [CrossRef]

22. Contractor, M.; Luna, G.; Patel, S.; Steinberg, S. Decision Support and Planning Tool to Facilitate Urban Rooftop Farming. In Proceedings of the 2020 Systems and Information Engineering Design Symposium (SIEDS), Charlottesville, VA, USA, 23-24 April 2020; pp. 5-10. [CrossRef]

23. Gajbe, P.U. Urban rooftop farming-Model for sustainable vegetable production and environmental well-being. Agric. Sci. Dig. 2021, 41, 211-214. [CrossRef]

24. Grard, B.J.P.; Chenu, C.; Manouchehri, N.; Houot, S.; Frascaria-Lacoste, N.; Aubry, C. Rooftop farming on urban waste provides many ecosystem services. Agron. Sustain. Dev. 2018, 38, 2. [CrossRef]

25. Toboso-Chavero, S.; Madrid-López, C.; Villalba, G.; Gabarrell Durany, X.; Hückstädt, A.B.; Finkbeiner, M.; Lehmann, A. Environmental and social life cycle assessment of growing media for urban rooftop farming. Int. J. Life Cycle Assess. 2021, 26, 2085-2102. [CrossRef]

26. Ledesma, G.; Nikolic, J.; Pons-Valladares, O. Bottom-up model for the sustainability assessment of rooftop-farming technologies potential in schools in Quito, Ecuador. J. Clean. Prod. 2020, 274, 122993. [CrossRef]

27. Harada, Y.; Whitlow, T.H.; Todd Walter, M.; Bassuk, N.L.; Russell-Anelli, J.; Schindelbeck, R.R. Hydrology of the Brooklyn Grange, an urban rooftop farm. Urban Ecosyst. 2018, 21, 673-689. [CrossRef]

28. Rufí-Salís, M.; Petit-Boix, A.; Villalba, G.; Ercilla-Montserrat, M.; Sanjuan-Delmás, D.; Parada, F.; Arcas, V.; Muñoz-Liesa, J.; Gabarrell, X. Identifying eco-efficient year-round crop combinations for rooftop greenhouse agriculture. Int. J. Life Cycle Assess. 2020, 25, 564-576. [CrossRef]

29. Jing, R.; Hastings, A.; Guo, M. Sustainable Design of Urban Rooftop Food-Energy-Land Nexus. iScience 2020, 23, 101743. [CrossRef]

30. Sanjuan-Delmás, D.; Llorach-Massana, P.; Nadal, A.; Ercilla-Montserrat, M.; Muñoz, P.; Montero, J.I.; Josa, A.; Gabarrell, X.; Rieradevall, J. Environmental assessment of an integrated rooftop greenhouse for food production in cities. J. Clean. Prod. 2018, 177, 326-337. [CrossRef]

31. Ercilla-Montserrat, M.; Muñoz, P.; Montero, J.I.; Gabarrell, X.; Rieradevall, J. A study on air quality and heavy metals content of urban food produced in a Mediterranean city (Barcelona). J. Clean. Prod. 2018, 195, 385-395. [CrossRef]

32. Ainun, N.; Maneepong, S.; Suraninpong, P. Effects of Photoradiation on the Growth and Potassium, Calcium, and Magnesium Uptake of Lettuce Cultivated by Hydroponics. J. Agric. Sci. 2018, 10, 253. [CrossRef]

33. Rouphael, Y.; Cardarelli, M.; Rea, E.; Colla, G. The influence of irrigation system and nutrient solution concentration on potted geranium production under various conditions of radiation and temperature. Sci. Hortic. 2008, 118, 328-337. [CrossRef]

34. Fallovo, C.; Rouphael, Y.; Cardarelli, M.; Rea, E.; Battistelli, A.; Colla, G. Yield and quality of leafy lettuce in response to nutrient solution composition and growing season. J. Food Agric. Environ. 2009, 7, 456-462.

35. Hartz, T.K.; Johnstone, P.R.; Williams, E.; Smith, R.F. Establishing lettuce leaf nutrient optimum ranges through DRIS analysis. HortScience 2007, 42, 143-146. [CrossRef]

36. Waechter-kristensen, B.; Caspersen, S.; Adalsteinsson, S.; Sundin, P.; Jensen, P. Organic compounds and micro-organisms in closed hydroponic culture. In International Symposium on Growing Media and Hydroponics; Acta Hort. 481; ISHS: Leuven, Belgium, 1999. 